\title{
Using Life Cycle Approaches to Enhance the Value of Corporate Environmental Disclosures
}

\author{
Josef Kaenzig, ${ }^{1,2 *}$ Damien Friot, ${ }^{3,2}$ Myriam Saadé, ${ }^{4,2}$ Manuele Margni ${ }^{5,6}$ and \\ Olivier Jolliet ${ }^{7,2}$ \\ ${ }^{1}$ The Institute for Economy and the Environment, University of St. Gallen, Switzerland \\ ${ }^{2}$ Ecole Polytechnique Fédérale de Lausanne (EPFL), Switzerland \\ ${ }^{3}$ Center for Energy and Processes, Mines-Paristech, France \\ ${ }^{4}$ University of Lausanne, Switzerland \\ ${ }^{5}$ CIRAIG, École Polytechnique de Montréal, Canada \\ ${ }^{6}$ Quantis, Lausanne, Switzerland \\ ${ }^{7}$ Center for Risk Science and Communication, University of Michigan, USA
}

\begin{abstract}
As the focus of environmental policy and management shifts from cleaner production at the process level towards greener products as a whole, stakeholders ask for transparency throughout the entire value chain. This article assesses the comprehensiveness and the value of currently reported quantitative environmental disclosures of 97 listed companies from the automotive, banking, pharmaceutical and electronic hardware sectors. Findings indicate that quantitative environmental disclosures have many limitations, including incompleteness and inconsistency regarding corporate activities and sites, and limited internal data coherence. For many sectors, corporate disclosures only cover a very small share of the total environmental burden of products. A stepwise procedure is proposed to verify and improve the quality and completeness of reporting using life cycle approaches. We present simple data quality tests, and we introduce the concept of the environmental influence matrix, which provides a solid basis for the identification and prioritization of key performance indicators and areas of action. Copyright (C) 2009 John Wiley \& Sons, Ltd and ERP Environment.
\end{abstract}

Received 9 February 2009; revised 30 September 2009; accepted 5 October 2009

Keywords: corporate environmental disclosure; input-output and process-based life cycle assessment (LCA); environmental performance; environmental reporting; sustainable development

\section{Introduction}

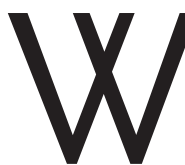

ITH RISING PUBLIC AWARENESS, STEADILY GROWING VOLUMES OF SUSTAINABLE RESPONSIBLE INVESTMENTS (SRI) and increasing financial risks due to environmental and energy issues in the last two decades, the interest and need for corporate environmental evaluation and corporate sustainability is growing (Gray et al., 200I; Cormier and Magnan, 2003; Kolk et al., 2005). Corporate environmental and

* Correspondence to: Josef Kaenzig, Institute for Economy and the Environment, Tigerbergstrasse 2, 90oo St.Gallen, Switzerland. E-mail: jkaenzig@yahoo.de 
sustainability reports are one way to meet stakeholders' needs for corporate environmental information, and they provide evidence of corporate sustainability assessments. There are other sources such as environmental labels and product declarations (ISO I4020 series), life cycle assessments (ISO I4040 series), pollutant release and transfer registries (e.g. the Toxics Release Inventory (TRI) and the European Pollutant Emission Register (EPER)) and macro-evaluations of industry sectors (e.g. Tukker et al., 2006). While complementary, these sources are rarely combined, probably because of their different scopes (products versus company versus sector) and target groups. We suggest combining these approaches in a consistent evaluation framework to increase the quality and reliability of current corporate environmental evaluation and disclosure. This article addresses both stakeholders' interests in the quantitative evaluation of the corporate environmental performance and the interests of managers in new concepts and tools to improve environmental self-evaluation and company disclosure. The article proposes a stepwise procedure based on life cycle approaches to verify and improve the quality and comprehensiveness of quantitative corporate environmental disclosure. It illustrates the approach by analyzing the disclosures of large companies from four sectors and also shows how to improve it.

\section{Existing Frameworks for the Evaluation of Corporate Sustainability}

To overcome the limitations of pure financial reporting and to satisfy newer information requirements for decision-making processes and communication policies (Schaltegger and Wagner, 2006), various stakeholder frameworks for environmental or sustainability evaluation and reporting have been proposed in the past years (Perrini and Tencati, 2006; Yongvanich and Guthrie, 2006; Castro and Chousa, 2006; Pflieger et al., 2005, etc.). They can be found in numerous voluntary standards and tools that have been developed for environmental management and reporting in the last two decades by standard-setting bodies such as the International Organization for Standardization (ISO), the Global Reporting Initiative (GRI), the Association of Chartered Certified Accountants (ACCA) and Business in the Environment (BiE) (for an overview see Kolk et al., 2005).

The KPMG survey on corporate sustainability reporting (Kolk et al., 2005) found that the most common guidelines used to determine report content were the Sustainability Reporting Guidelines from the GRI, with $40 \%$ of reports referring to it. The GRI aims at standardizing corporate sustainability reporting with an extensive framework of indicators. As far as the environmental performance indicators are concerned, the framework distinguishes between nine aspects: materials; energy; water; biodiversity; emissions, effluents and waste; products and services; compliance; transport; and total environmental protection expenditures and investments (GRI, 2006). While this may appear exhaustive, three critiques can be addressed. First, the majority of GRI indicators relate to site-specific energy and material inputs and outputs, neglecting the environmental burdens occurring upstream and downstream of the company site. The bulk of the environmental load of many products and services, however, occurs either upstream, in the supply chain, or downstream, in the use phase or at the end of the life cycle (Tukker et al., 2006; Labouze et al., 2003; Kaenzig and Jolliet, 2007, 2006). Second, as stated by Butz (2005) in an article on how to rate companies for sustainable investment funds, 'less is more'. A restricted number of product and industry-specific key environmental indicators, rather than an extensive voluntarily reporting of environmental indicators restricted to the site level, would result in a more focused assessment identifying the relevant differences among companies. Third, the voluntary character of the GRI framework allows companies to emphasize the positive aspects of their environmental performance in the reporting (Niskanen and Nieminen, 200I) and to omit important environmental indicators that suggest poor environmental performance. One way rating agencies can tackle the problem of missing indicators and values is to substitute any missing value with a value representing poor environmental performance compared with other companies' reports (Weber et al., 2008).

Environmental management and policy measures are moving from cleaner production concepts at the process level to more integrated and holistic approaches that extend producer responsibility to the whole life cycle of products and services (Kautto, 2006; Lenzen et al., 2007). This, for example, is the case in the Integrated Product Policy (IPP) of the European Commission. An important and holistic approach that incorporates life cycle thinking is life cycle assessment (LCA). LCA is an established analytical approach to determine the environmental impacts and identify improvement opportunities of products and services. It is based on ISO standards (ISO I4O4O seqq.) and is actively promoted by the United Nations Environment Program (UNEP). An econometric analysis from Rehfeld et al. (2006) showed that LCA is the most effective voluntary organizational measure to promote 
environmental innovations. The use of LCA is indeed increasing amongst financial service providers (Centre Info, 2007; Trucost, 2007). There has also been important progress in the quantification of total environmental burdens due to total consumption activities of countries or per capita consumption (see, e.g., Tukker and Jansen, 2006). However, since LCA has traditionally focused on products rather than corporations, little research has focused on life cycle approaches to corporate environmental disclosure. In the next section, we present possibilities for linking LCA to corporate environmental disclosure.

\section{Limitations of Current Quantitative Corporate Environmental Disclosure}

Research contributions on voluntary environmental disclosures have analyzed the nature and content of environmental disclosures (Brammer and Pavelin, 2006). Existing empirical literature typically measured the quality of voluntary environmental disclosures as the number of words or sentences, or the proportion of the annual report devoted to environmental information (Hackston and Milne, I996; Guthrie and Parker, I990). Brammer and Pavelin (2006) analyzed 450 UK companies, distinguishing between the following six indicators of the quality of corporate environmental disclosure: disclosure of an environmental policy, existence of board-level responsibility for environmental matters, the description of environmental initiatives, reporting on environmental improvements, setting of environmental targets and the presence of an environmental audit or assessment. Cormier et al. (2007) measured quality by taking into account the perceived precision, usefulness for decisionmaking and relevance of disclosed information. These assessments of environmental disclosures do not contain systematic evaluations of quantitative environmental disclosures. Hahn and Scheermesser (2006) analyzed a sample of 195 German companies, and Llena et al. (2007) analyzed the disclosure of 51 large Spanish companies; both studies found that about one-third of the companies disclosed quantitative non-financial data. It can be concluded that there are several publications evaluating the quality of voluntary environmental disclosures, but there is no scientific publication that systematically evaluates the quality of quantitative voluntary environmental disclosures.

Compulsory environmental disclosures have been used in several research contributions for the evaluation of environmental performance (Kerret and Gray, 2007; Kassinis and Vafeas, 2006; Freedman and Patten, 2004; Gerde and Logsdon, 200I), but their quality was also rarely investigated quantitatively. When seeking to compare and contrast the environmental performance at the company site level, the quality of compulsory environmental disclosure tends to be better than the quality of voluntary disclosure (Gouldson and Sullivan, 2007). However, since compulsory disclosures, such as TRI and EPER data, are also on an establishment and site level, they need to be linked to a unit of production in order to derive a measurement of corporate environmental performance.

Previous literature analyzed the nature of environmental disclosures and determinants, but there is little information on quality and completeness. We intend to fill this research gap and provide a methodology to improve the quality and accuracy of voluntary and compulsory environmental disclosures. The article aims at answering the following questions.

I) How reliable and accurate are quantitative corporate environmental disclosures and how can one verify their quality?

2) What share of environmental burdens within the life cycle of products and services does existing quantitative environmental reporting cover?

3) How can key performance indicators be identified for a reliable quantitative environmental evaluation and comparison of companies?

The next section develops a stepwise procedure based on the use of life cycle approaches for assessing and improving quantitative environmental disclosures of corporations. (I) The first step consists of analyzing the coverage and reliability of corporate environmental disclosures and is illustrated by an in-depth analysis of corporate environmental disclosure in the empirical section of this article. (II) The second step builds on Step I and introduces environmental burden and environmental influence matrices as a means to prioritize potential environmental gains. (III) Based on Step II, the third step determines which key indicators provide a sound basis for reliable environmental evaluation. All steps are illustrated by a case study from the automotive sector and are complemented by results from three other sectors. The concluding section provides implications 
for a comprehensive evaluation of corporate environmental performance and a discussion on the limitations of the present work.

\section{Methodology and Framework for Corporate Environmental Evaluation}

\section{Methodological Background of Quantitative Life Cycle Approaches}

Life cycle approaches identify both opportunities and risks of a product or technology, all the way from raw materials to disposal (UNEP, 2004). To do this, there is a continuum of life cycle approaches from qualitative (life cycle thinking) to well established quantitative approaches (LCA studies, ISO I4040 series ${ }^{\mathrm{I}}$ ).

The traditional process-based LCA analyzes the whole life cycle (production, use and disposal) of products or services (for an introduction to the methodology see Rebitzer et al., 2004; Pennington et al., 2004). We used two main types of process-based LCA data source - the ecoinvent database (Frischknecht et al., 2005), which is the most comprehensive life cycle inventory database, covering more than 3000 products and processes, and results from process LCA studies taken from the literature.

Input-output analysis is founded on research carried out by Wassilij Leontief (I936). Leontief's input-output model gave birth to the so-called input-output LCA, which complements process-based LCA. This method links national-level economic input-output tables with databases on environmental releases per sector (for an introduction see Suh and Nakamura, 2007; Suh, 2004). Input-output tables exist for many countries (Suh et al., 2004; Moll and Watson, 2009; Tukker et al., 2009). When analyzing international companies the Bureau of Economic Analysis input-output accounts are generally most suitable, as they are the most detailed. They differentiate the production of roughly 500 different commodities and services by roughly 500 different sectors (BEA, I997).

Table I summarizes the life cycle coverage, as well as advantages and disadvantages, of different approaches to generate corporate environmental disclosures. Process-based LCA requires very detailed input data for the analyzed products, but has the advantage of being accurate and precise for specific systems. Input-output LCA enables quick estimates of the environmental impact of a certain output of industry sectors by taking into account all suppliers, but is limited in precision by the high levels of aggregation of commodities. The use of both process-based and input-output-based LCA is called hybrid LCA (Hertwich, 2005; Suh and Nakamura, 2007) and combines the advantages of each method. New databases (Frischknecht et al., 2005) and hybrid LCA methodology using linear algebra (Suh, 2004) now allow simultaneous computation of a large number of environmental indicators and emission categories. Emissions are aggregated into impact or damage categories using life cycle impact assessment methods to reduce the number of indicators. A review of these methods is presented by Pennington et al. (2004).

\section{Data and Method}

Analyses for this paper are based on four main data sources. The starting point is the database on non-financial profiles of 600 of the world's largest joint stock companies, commercialized by the SiRi Company (2003). This database is used for internal rating by banks, pension funds and other members of the financial community. For this research, the quantitative environmental data of the automobile, banking, pharmaceutical and electronic hardware sector were extracted and compared with quantitative process-based LCA studies, and national

\footnotetext{
${ }^{\mathrm{I}}$ Life cycle assessment (LCA) is defined by ISO I4040 (2006) as the compilation and evaluation of the inputs, outputs and the potential environmental impacts of a product system throughout its life cycle. There are four phases in an LCA study:

(a) defining a goal and scope including system boundary and level of detail;

(b) compiling a life cycle inventory (LCI) of relevant inputs and outputs of a product system;

(c) evaluating the potential environmental impacts associated with these inputs and outputs;

(d) interpreting the results of the inventory analysis and/or impact assessment phases in relation to the objectives of the study.

Applications of life cycle assessment listed by ISO I4040 (2006) include amongst others product development and improvement, environmental performance evaluation (ISO I4O3I and ISO/TR I4032), identification of significant environmental aspects of the products and services of an organization, environmental labels and declarations (ISO I4020, ISO I4O2I and ISO I4O25), and validation, verification and certification of greenhouse gas emissions (ISO I4064).
} 


\begin{tabular}{|c|c|c|c|}
\hline Life cycle stage & $\begin{array}{c}\text { Traditional corporate env. } \\
\text { evaluation and reporting; } \\
\text { Pollutant Release and Transfer } \\
\text { Register (e.g. TRI, EPER) }\end{array}$ & $\begin{array}{l}\text { Input-output life cycle } \\
\text { assessment (extended } \\
\text { input-output analysis) }\end{array}$ & $\begin{array}{c}\text { Process-based life cycle } \\
\text { assessment; environmental } \\
\text { product declarations }\end{array}$ \\
\hline Supply chain & & $x$ & $x$ \\
\hline Companies' establishments & $x$ & $x$ & $x$ \\
\hline Disposal & & $(X)$ & $x$ \\
\hline Data basis & $\begin{array}{l}\text { Self-assessments by } \\
\text { companies }\end{array}$ & $\begin{array}{l}\text { Aggregated data from } \\
\text { compulsory } \\
\text { environmental disclosure, } \\
\text { national accounts and } \\
\text { inventories }\end{array}$ & $\begin{array}{l}\text { LCA databases, LCA studies } \\
\text { often carried out or } \\
\text { verified by independent } \\
\text { organizations }\end{array}$ \\
\hline Weakness & $\begin{array}{l}\text { Restricted coverage of } \\
\text { company sites and life cycle } \\
\text { stages }\end{array}$ & $\begin{array}{l}\text { Aggregation of similar } \\
\text { commodities, age of } \\
\text { data, data based on } \\
\text { economic activities of } \\
\text { one specific year }\end{array}$ & $\begin{array}{l}\text { Truncation of small inputs } \\
\text { and outputs, age of data }\end{array}$ \\
\hline
\end{tabular}

Table 1. Comparison of approaches for generating corporate environmental data and their typical coverage of the life cycle

accounts-based input-output LCA studies. The procedure and the LCA approaches are further described in the next paragraph.

\section{Stepwise Procedure for Corporate Environmental Evaluation}

We propose a procedure for the evaluation and improvement of quantitative corporate environmental disclosures in three steps. The first step consists of analyzing and improving the coverage and reliability of quantitative corporate environmental data. The second step builds on findings from Step I and introduces environmental burden and environmental influence matrices as a means to prioritize potential environmental gains. Based on Steps I and II, the third step consists of determining which environmental key performance indicators provide a sound basis for reliable environmental evaluation. Of course, each step and tool can be applied independently from the other steps if the needed data is available.

Step I: Analysis of the Coverage and Reliability of Corporate Environmental Disclosures

To be able to use environmental disclosures, we need to understand what is included (i.e. what are the boundaries of the system), and we need to test the quality of reported data. This first step requires gathering information on companies' activities related to the product portfolio, turnover distribution, environmental and sustainability reports, and other external environmental information.

The identification of the system boundaries clearly sets what is covered and left out by the reports and how representative this is of the activities of the company as a whole. Corporate environmental disclosures often do not cover all activities and all production sites of a company. Disclosures may only be valid for the parent company or represent just a certain share of the turnover. Figures are sometimes only valid for plants in Europe or only for ISO I400I certified plants. Moreover, disclosures very rarely cover the whole life cycle of a product, often neglecting the prior production chain and use and disposal phases. Considering the current trend of off-shoring production processes and wastes that have high environmental impacts, the coverage of the whole life cycle of products is critical to the quality of the environmental evaluation. Therefore the geographical coverage, the coverage of the 
turnover and of the life cycle (supply chain, production site, use stage and disposal), must always be verified when using or interpreting quantitative environmental disclosures.

Quality tests provide information on the plausibility of the corporate environmental disclosure. The simplest ones are cross-checks with companies in the same economic sector. These tests are however limited to particular cases as there are few companies with the same product portfolio and the same level of integration within the supply chain.

In addition, environmental figures reported by a company can be compared with references based on physical constraints to test the coherence of disclosed data. For example, the ratio between carbon dioxide emissions and energy consumption reported by companies should lie within a narrow range depending on combustion and fuel types: this ratio amounts to around 55 grams of $\mathrm{CO}_{2}$ per megajoule of primary energy for natural-gas-based technology, 65 for oil based and 85 for coal based. For electricity generation, this ratio decreases as a function of the share of non-fossil energy in the electricity mix (Figure I). For completely fossil-based electricity supply, the share

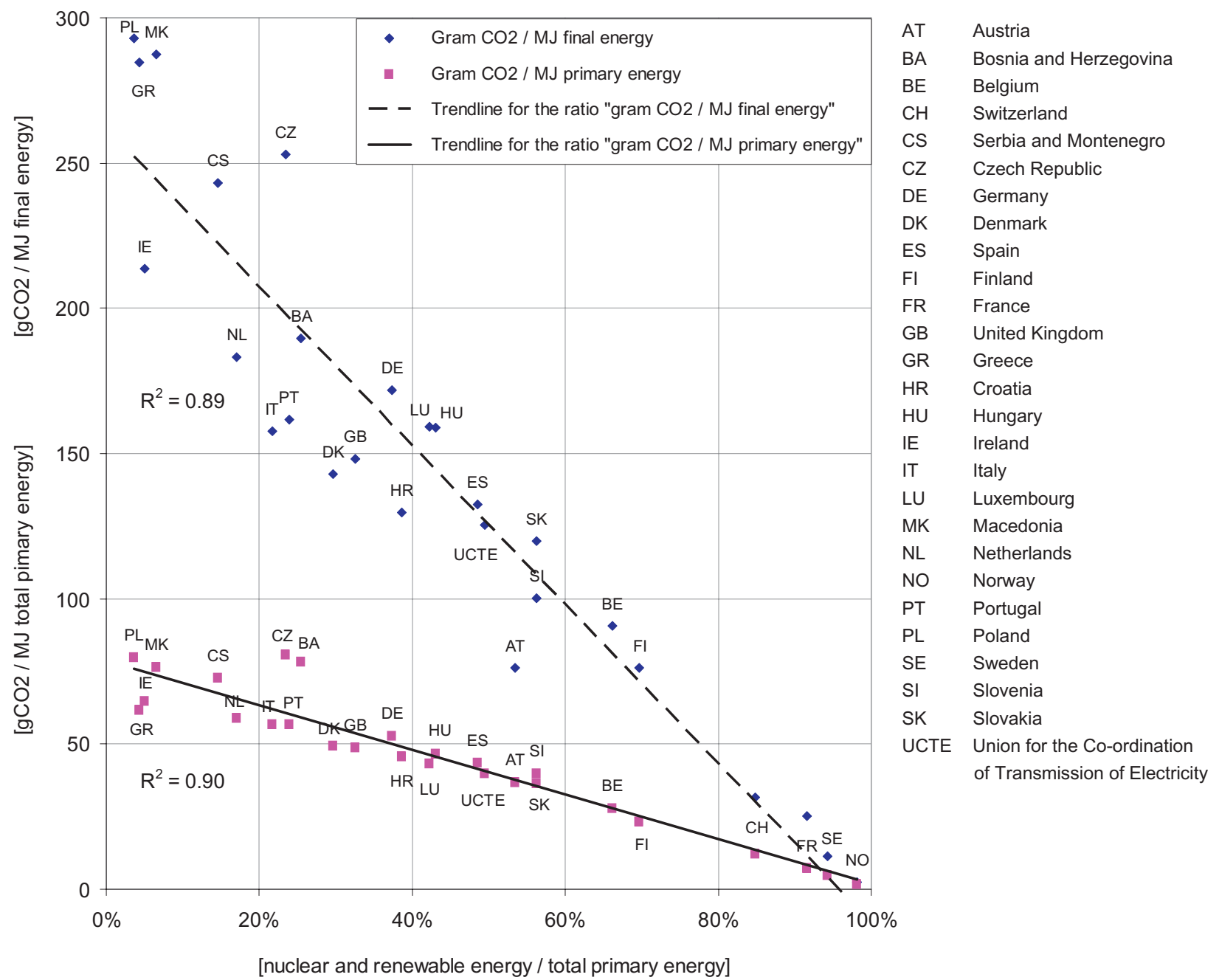

Figure 1. Carbon dioxide emissions per unit primary and final energy as a function of the share of non-fossil (nuclear and renewable) energy carriers used for the production of electricity. Calculations are based on ecoinvent 1.3 (2004) for different European electricity supply mixes. Total primary energy includes all energy inputs for the production of one unit of electricity. The final energy is the energy effectively delivered to the end consumer 
of nuclear and renewable energy is close to zero and the ratio of carbon dioxide emissions to primary energy use is close to $70 \mathrm{~g} \mathrm{CO}_{2} / \mathrm{MJ}$, as expected.

A further possibility to verify the completeness and the reliability of quantitative corporate environmental disclosure is comparison with existing LCA studies. The environmental impact of the product portfolio of a company can be rebuilt by adding up the environmental impacts of each product sold. LCA studies can also be used to complete insufficient quantitative corporate environmental disclosures.

Step II: Environmental Burden and Environmental Influence Matrices - Prioritization of Potential Environmental Gains

Environmental impact studies such as process-based and input-output-based LCA provide information on the main impacts of the commodities produced by a company. They also reveal where these impacts occur over the whole production-consumption-disposal chain. In combination with studies about environmental risks of company activities, they may help to quickly focus on major environmental impacts and potential environmental improvements.

As most companies produce several commodities, all of them need to be accounted for in the methodological approach to model product portfolios. PSA Peugeot Citroen can be used as an example since its product portfolio corresponds quite well to the average portfolio of a car manufacturing company (SiRi Company, 2003). 2002 revenues of PSA Peugeot Citroen accrued to $76 \%$ from automobile manufacturing, $17 \%$ from manufacturing of automotive equipment, $5 \%$ from transportation and logistics and $2 \%$ from financing and other businesses. The composite input-output equivalent can be built up in the following way.

I. Identification of the main products of the company based on its turnover. ${ }^{2}$

2. Determination of corresponding input-output commodities (in this article BEA (I997) is used).

3. Choice of the unit of comparison and normalization of the environmental indicators.

4. Computation of environmental indicators for each product and economic sector (Figure 2 below provides an example for the automotive sector and carbon dioxide emissions per million US dollars of output).

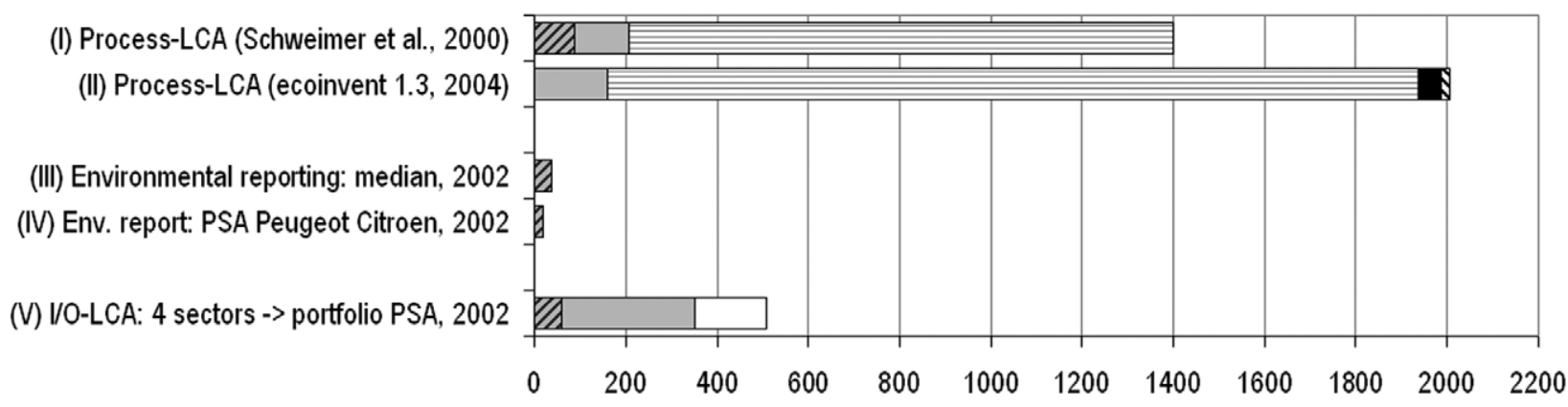

Carbon dioxide emissions [ton of $\mathrm{CO}_{2}$ /million US\$ output]

Production site \& $\mathrm{CO}_{2}$ due to its energy consumption
Supply chain of the vehicle production
Services (excluded in process-LCA)
Use stage of the car (fuel production incl.)
Road infrastructure

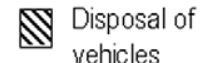
vehicles

Figure 2. Carbon dioxide emissions due to one million US dollar output in the automotive sector

\footnotetext{
${ }^{2}$ A company portfolio is well represented by turnover figures. The emissions due to a specific step in the value chain are best represented by value added. As figures on the value added per product are not available in most cases and as they are calculated in various ways, a comparison using turnover provides the most interesting insights. It is also compatible with extended producer responsibility, assigning the responsibility to the company selling to the end user.
} 
5. Weighting and aggregation of the input-output values in order to recreate the product portfolio of the company.

An essential additional step is to complete the quantitative assessment with a qualitative analysis of aspects that are not easily quantified. Due to the lack of site-specific knowledge for the evaluation of local impacts and the lack of scientific knowledge on emerging impacts such as endocrine disrupters or electromagnetic radiation, it is not always possible to quantify all environmental impacts. It is therefore important to use a method considering these non-quantified burdens in parallel with what can be measured. The environmental burden matrix introduced by Dyllick et al. (I994) is a first possibility. It presents the distribution of the environmental burden for each life cycle stage of an industry sector, a company or a product (example presented in Figure 3 for a car). Within a qualitative assessment with expert interviews, Dyllick et al. (I994, I997) determined environmental burden matrices for many

\begin{tabular}{|c|c|c|c|c|}
\hline \multicolumn{5}{|c|}{$\begin{array}{l}\text { ENVIRONMENTAL BURDEN MATRIX FOR A CAR } \\
\text { environmental impact of life cycle stages }\end{array}$} \\
\hline Life cycle stages & Infrastructure & Production & Use & Disposal \\
\hline \multicolumn{5}{|c|}{$\begin{array}{l}\text { Distribution of the environmental burden for } \\
\text { each life cycle stage }\end{array}$} \\
\hline \multirow{3}{*}{$\begin{array}{l}\text { Legend: } \\
\text { Environmental burden relative to the total } \\
\text { environmental burden }\end{array}$} & & \multicolumn{3}{|c|}{ Share of the environmental burden $>30 \%$} \\
\hline & & \multicolumn{3}{|c|}{$\begin{array}{l}\text { Share of the environmental burden from } \\
10 \% \text { to } 30 \%\end{array}$} \\
\hline & & \multicolumn{3}{|c|}{ Share of the environmental burden $<10 \%$} \\
\hline
\end{tabular}

\begin{tabular}{|l||||||||}
\hline \hline \multicolumn{3}{|c|}{ ENVIRONMENTAL INFLUENCE MATRIX FOR A CAR } \\
influence of actors and key decisions on the total environmental damage \\
\hline \multicolumn{2}{|c|}{ Life cycle stages } \\
Actors and key decisions
\end{tabular}

Figure 3. An environmental burden and influence matrix for the automotive sector (based on ecoinvent 1.3 (2004), Kaenzig and Jolliet (2006)) 
industry sectors. Three different levels (highly relevant, relevant and not relevant) were used to describe the environmental relevance of each life cycle stage within different damage categories. Allenby (2000) also used this concept and proposed an environmental evaluation matrix for materials and a matrix to create responsible products and processes. While traditionally based on expert interviews, we suggest basing the environmental burden matrix on robust quantitative data whenever feasible and creating a matrix for each important product group of the company.

We propose a further step to extend the environmental matrix approach to also identify key factors, key decisions and key actors in order to reveal potential improvements of the environmental balance. We therefore propose a second matrix called the 'environmental influence matrix', which displays the respective influence of actors and key decisions on the total environmental damage (example in Figure 3 below for a car). It can be drawn up in an analogous manner to the environmental burden matrix, applying quantitative methods (based on LCA) or qualitative methods (expert panels and interviews) for determining the potential environmental improvement. The potential environmental improvement is the difference between the environmental impact of an environmentally sound decision and a conventional decision with the same functional unit. The potential environmental improvement is computed for key decisions and corresponding strategies to reduce the environmental burden (Kaenzig and Jolliet, 2006, 2007). We further identified the actors who make key decisions regarding environmental impacts (see also Kaenzig and Jolliet, 2006, 2007; Berlin et al., 2008; Brunklaus et al., 2008). The environmental influence matrix shows the influence that actors and their decisions at each life cycle stage have on environmental performance. The level of influence is indicated in comparison to the total environmental burden of a product or product portfolio of a company over the whole product life cycle. The influence and potential improvements might be specified in absolute or relative values.

Step III: Environmental Key Performance Indicators - Choice of a Sound Basis for Reliable Environmental Evaluation

The choice of key performance indicators to measure the environmental performance or improvements is the last step. A reduced number of indicators that make up the preceding step-wise analysis makes communication easier and allows for tracing the improvement of key environmental issues. Key performance indicators result from a comprehensive selection process (e.g. Steps I and II) and truly reflect the key environmental issues of product groups. They shift attention towards what is really essential for a given product or sector, acknowledging the fact that each sector has a specific contribution to make to reduce the overall environmental burden, and that this contribution is better dealt with at some stages of the life cycle than others. As a result, key performance indicators

(i) reflect the function (or the need satisfied) of the product that will finally be sold to the consumer and

(ii) consider a life cycle perspective to include the most important impacts on the whole production-consumptiondisposal chain.

\section{Analysis and Empirical Illustration with Case Studies}

\section{Step I: Analysis of the Coverage and Reliability of Corporate Environmental Disclosure}

In this section the methodological framework is illustrated with results from the automotive, banking, electronic hardware and pharmaceutical sectors. The most frequently published environmental indicators in these sectors are presented in Table 2.

Quantitative indicators in environmental disclosures cover mainly energy and water consumption, industrial waste and greenhouse gases. Particles were considered by only one automotive company, even though they are a key environmental issue for transportation (Kaenzig and Jolliet, 2006). The considered system boundaries vary from company to company, both regarding the share of sites and the turnover covered. Quantitative environmental disclosures often cover only a small number of sites and consider mainly direct impacts. In some cases, upstream (indirect) impacts linked to the electricity consumption of companies' establishments were also 


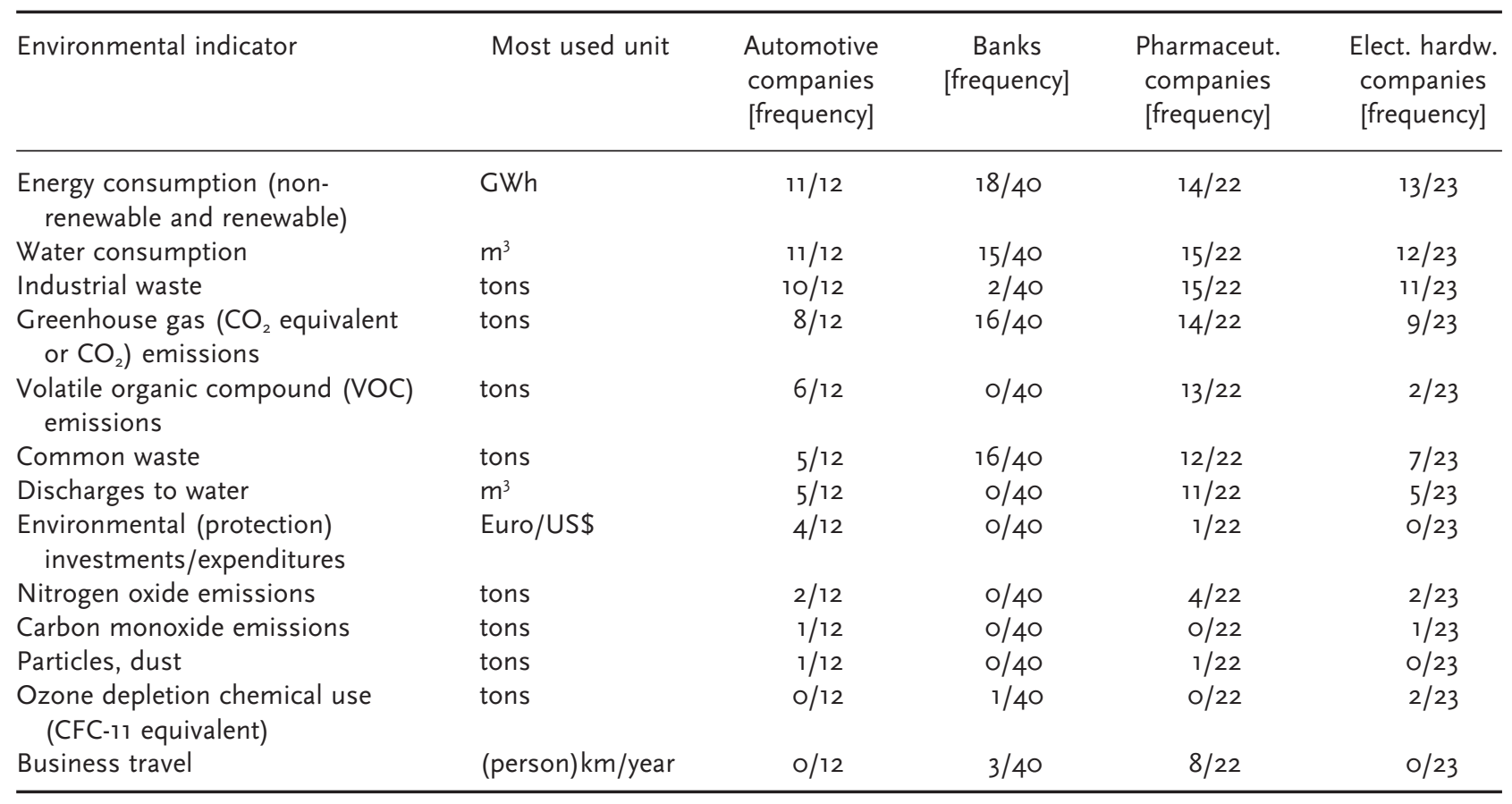

Table 2. Most frequently published environmental figures by 12 automotive companies ${ }^{(1)}, 40$ banks, 22 pharmaceutical companies and 23 companies in the electronic hardware sector (based on SiRi Company $(2003)^{(2)}$ )

(1) BMW, Daimler Chrysler, Fiat, Ford, General Motors, GKN, Honda, Mitsubishi, Porsche, PSA Peugeot Citroën, Toyota, Volkswagen.

(2) The database from 2003 is used because it is the most complete as far as quantitative environmental figures are concerned.

considered. Very few companies disclosed quantitative figures on impacts of suppliers or on impacts occurring during the use stage of their products. Those findings are consistent with Kolk et al. (2005) stating that $67 \%$ of corporate responsibility reports measure and report on the amount of direct greenhouse gas (GHG) emissions from their own business operations. They also found that reporting of indirect emissions is much lower, with $33 \%$ reporting emissions from purchased electricity and $26 \%$ reporting emissions from other sources, including transportation or emissions associated with the use of the company's products or services.

Quality tests with cross-checks within economic sectors comparing environmental indicators per turnover (e.g. greenhouse gases per turnover) reveal considerable differences between companies as well as erroneous values (some emissions were too high but most were underestimated). To decrease the bias due to erroneous values, we suggest using the median value of each sector for the comparison of environmental disclosures of companies in the same sector, rather than the average. Comparisons per turnover are restricted to comparisons among companies with similar product portfolios and similar levels of integration within the supply chain.

The second test with the ratio of carbon dioxide emissions ${ }^{3}$ to energy consumption reveals that about $20 \%$ of the world's biggest companies from the automotive, banking, pharmaceutical and hardware sectors disclosed inconsistent figures. In each of the four sectors there is at least one company disclosing figures that lead to a ratio greater than $10000 \mathrm{~g} \mathrm{CO}_{2} / \mathrm{MJ}$, which is simply impossible from a physical point of view. The ratio for most of the remaining $80 \%$ of companies analyzed is plausible and lies between I and $300 \mathrm{~g} \mathrm{CO}_{2} / \mathrm{MJ}$. The usual ranges are $30-80 \mathrm{~g} \mathrm{CO}_{2} / \mathrm{MJ}$ primary energy or $80-300 \mathrm{~g} \mathrm{CO}_{2} / \mathrm{MJ}$ final energy. These ratios are valid for all types of environmental evaluation, unless the commodities or companies assessed make heavy use of non-fossil energy,

${ }^{3}$ No distinction between $\mathrm{CO}_{2}$ emissions and $\mathrm{CO}_{2}$ equivalent figures was made, because the error due to this omission is small in comparison with the range of the ratio. 
in which case the ratio will be smaller (cf. Figure I). Three potential explanations of values being outside the usual range are that (i) the system boundaries (spatial coverage) of the two figures disclosed are not congruent, (ii) the energy figure or the carbon dioxide emission figure is erroneous or (iii) the company uses a non-fossil energy mix such as electricity or heating based on nuclear power, biomass, biogas, geothermal, wind, photovoltaic, and wave or tidal power. Based on the 97 companies examined here, it can be concluded that the analyzed quantitative environmental disclosures reveal a lack of coherence at the sectoral and the company level. Any use of data for measuring the improvement of companies' environmental performance is therefore only meaningful after external verification.

Verification and Completion of Corporate Environmental Disclosures using Life Cycle Assessment LCA studies make it possible to analyze which share of environmental burdens of a product are included in environmental disclosures, and they can be used to complete environmental disclosures. This section illustrates how carbon dioxide emissions disclosed by companies compare with total carbon dioxide emissions during the whole life cycle of their products.

We first demonstrate the range in emission estimates resulting from applying different methods to the automotive sector. ecoinvent (2004) provides an LCA dataset for a generic car in the European Union with an average gasoline consumption of about 7.8 liters per roo kilometers (cf. II in Figure 2). Schweimer and Levin (2000) assessed the life cycle environmental impact of a Volkswagen Golf. This study distinguishes the environmental impact at the production site from impacts in the supply chain of Volkswagen (cf. I in Figure 2). These first two results (I and II) show that the use stage is clearly the most important stage for the automotive sector as far as carbon dioxide emissions are concerned. The same finding is valid for other damage categories (human health, ecosystem quality, resources and climate change) (ecoinvent I.3, 2004; Kaenzig and Jolliet, 2006). In comparison, the median value of carbon dioxide emissions disclosed by i2 automotive companies represents a very small share of the total carbon dioxide emissions over the whole life cycle of a vehicle (cf. III in Figure 2).

These findings illustrate that it does not make sense to compare the environmental performances of automotive companies based on current corporate environmental disclosures. This is limited to on-site (direct) environmental impacts of the establishments of the company only, which is not representative of the whole life cycle of products and services. A combination of different life cycle approaches seems more adequate to assess the environmental performance of companies, since a larger number of impacts can be considered and the reliability and accuracy of the assessment increases.

Excluding the use phase and looking at production only, input-output LCA computations enable the determination of the direct as well as the indirect (upstream) emissions (Suh, 2004; Rebitzer, 2005, Suh and Nakamura, 2007). The share of $\mathrm{CO}_{2}$ emissions due to and reported by companies producing cars is four times smaller than the share of total carbon dioxide emissions occurring in the car supply chain (cf. I, III, IV and V in Figure 2). This is consistent with other industry sectors; using input-output tables it can be shown that indirect or supply chain emissions are more important than direct emissions during manufacturing for a majority of the 490 industry sectors defined for the US economy. Exceptions are the utility sector, sectors producing intermediate products such as primary metals or, more generally, sectors fulfilling early steps of the value chain, and sectors covering almost the whole production chain.

For the banking sector, the share covered by corporate environmental disclosures is about $40 \%$ as far as on-site energy consumption and carbon dioxide emissions are concerned. Furthermore, the supply chain of a bank induces about five times more greenhouse gas emissions than the bank itself. This estimate does not take into account the environmental burdens and improvement potential associated with investment strategies and credit policies, where the highest potential for improvement of the environmental balance of banks lies. Providing favorable loans and mortgages for environmentally sound projects is an example of how banks can influence their environmental balance (Weis, 2007).

Energy and carbon dioxide figures disclosed by companies in the pharmaceutical sector compare reasonably well to data from LCA about direct energy consumption and emissions. However, similar to the banking sector, the supply chain causes much more greenhouse gas emissions and energy consumption than the production site of the last company in the value chain. 
For the electronic hardware sector, LCA figures for energy consumption also exceed energy figures disclosed by companies producing mobile phones, computers and other electronics. The share of the energy consumption of the supply chain is even higher for companies in the hardware sector than for companies in the automobile, banking and pharmaceutical sectors.

Carbon dioxide emissions are used here as an example, demonstrating that using reported data on direct emissions of companies is not satisfactory as it covers neither the use phase nor the supply chain. Note that carbon emissions do not provide a comprehensive stand-alone indicator for the assessment of the environmental performance of a company and need to be complemented by other indicators, especially for pharmaceutical and electronic hardware companies. The following two chapters illustrate how key performance indicators can be determined.

\section{Step II: an Environmental Burden and Influence Matrix for Cars}

A synthetic example of an environmental burden and an environmental influence matrix is shown in Figure 3 for car-producing companies. It is based on the LCA studies cited in the preceding paragraphs. The impact assessment was completed by an expert panel. We consider that good practice in LCA requires using at least two environmental impact assessment methods and an expert review. The two LCA methods employed here are IMPACT 2002+ (Jolliet et al., 2003) and Ecological Scarcity (Braunschweig et al., I997).

The environmental burden matrix shows that the use stage causes the highest share of environmental burdens in all impact categories, as shown earlier in Figure 2. The environmental influence matrix shows that decisions made by producers have a very high influence on the environmental burden (follow row $\mathrm{C}$ to the right to see the influence on the environmental burden). The same applies to decisions by legislators and regulators, and consumers. Decisions made by suppliers have a significant but restricted influence on the environmental burden. It can be concluded that the use stage of cars causes the highest environmental burden and that the highest potential for improvement of the environmental balance can also be found in the use stage of the car. The environmental influence matrix further reveals that car producers have a very high influence on the environmental balance of the use phase (e.g. through the design of the car and resulting gasoline consumption per kilometer, the choice of the motor technology and the car types they market). The consumer has an important influence when choosing a car, when driving the car and of course by choosing the mode of transport and the frequency of traveling, both of which influence the number of miles driven yearly.

\section{Step III: Identification of a Sound Basis for Reliable Environmental Evaluation}

Environmental key performance indicators aim to summarize findings from the environmental evaluation and can be based, for instance, on the evaluation described in the preceding steps. A key performance indicator for the automotive sector resulting from our analysis is 'average carbon dioxide emissions per passenger kilometer of a generic car representative of the whole vehicle fleet'. This indicator includes both a technological component (grams of $\mathrm{CO}_{2}$ emitted by kilometer for each vehicle) and a strategy component (sales by type of vehicle worldwide), resulting in average emissions for a generic car of the company. Carbon dioxide emissions are chosen because transport is a key factor in global warming and was responsible for $23 \%$ of world energy-related greenhouse gas emissions in 2004, with about three-quarters coming from vehicles on the road (Kahn Ribeiro et al., 2007). They are also strongly correlated to the energy consumption during the production and use of a car. This indicator could be complemented with indicators for human health, such as the emissions of particulate matter up to Io micrometers in size (PMIO) and nitrogen oxides $\left(\mathrm{NO}_{x}\right)$ per passenger kilometer, or the share of the fleet that meets the highest emission standards of the European directives 70/220/EEC, 93/59/EC, 96/69/EC and 98/69/EC.

We constructed this key performance indicator for a generic 2003 car model for a selection of automobile companies and compared it with other ranking systems valid for the same year (Table 3). The generic model is a weighted sum of models sold on the Western European market (Automotive News, 2003) and $\mathrm{CO}_{2}$ emission factors per kilometer (TCS and EnergieSchweiz, 2004). ${ }^{4}$ We compare it with (a) a simple synthetic indicator summing the share of car models sold by different car producing companies in categories A and B from the energy-efficiency

${ }^{4}$ The same 'environmental key performance indicator' approach is currently applied by Centre Info (2007). 


\begin{tabular}{lccc}
\hline Company & $\begin{array}{c}\text { Gram of } \mathrm{CO}_{2} \text { /average } \\
\text { vehicle kilometer (key } \\
\text { performance indicator) }\end{array}$ & $\begin{array}{c}\text { Share of models with } \\
\text { A and B energy label in } \\
2003 \text { (synthetic indicator) }\end{array}$ & $\begin{array}{l}\text { Ranking based on } \\
\text { quantitative environmental } \\
\text { disclosure }\end{array}$ \\
\hline Fiat & $1(160)$ & 2 & 5 \\
VW & $2(176)$ & 1 & 2 \\
Toyota & $3(179)$ & 4 & 3 \\
Daimler Chrysler & $4(209)$ & 3 & 4 \\
BMW & $5(212)$ & 5 & 1 \\
Life cycle stage & Use & Use & Production \\
\hline
\end{tabular}

Table 3. Comparison of ratings of companies based on different data sources

label scheme of the Swiss Federal Office of Energy ${ }^{5}$ and (b) a ranking based on quantitative environmental disclosures. The simple synthetic indicator does indeed represent the effort by car makers to propose models that are energy efficient, but it does not include the fact that car makers influence sales through sales channels, advertisement and other means, which is covered by our key performance indicator of $\mathrm{g} \mathrm{CO}_{2} /$ average vehicle $\mathrm{km}^{6}$

The ranking with our 'key performance indicator' approach is almost opposite to the ranking established using carbon dioxide emission figures published in environmental reports and other corporate disclosures that focus on the restricted direct manufacturing emissions. Similar trends can be found between the energy label ranking and the ranking according to carbon dioxide emissions for the vehicle fleet of the companies. Corporate environmental reporting in the automotive industry is thus not only missing the key environmental issue of this industry from an environmental perspective as shown in Step II, but can also lead to poor decisions when this information is used by stakeholders.

\section{Discussion and Conclusions}

This article shows how life cycle approaches can increase the quality and the environmental relevance of current corporate environmental disclosure (a) by providing tools to analyze the coverage and the reliability of existing environmental disclosure (Step I), (b) by introducing the environmental influence matrix for the evaluation of the magnitude of potential environmental gains (Step II) and (c) by emphasizing the importance of basing reporting on key performance indicators that mirror the main environmental impacts and the potential environmental gains along the life cycle of products (Step III).

\section{Discussion of Findings and Avenues for Enhancing the Value of Quantitative Corporate Environmental Disclosure}

As far as the coverage of quantitative corporate environmental disclosures is concerned, it can be summarized that most quantitative corporate environmental disclosures are site specific and cover only production sites. Companies often employ in-house methods (see also Gerde and Logsdon, 200I) and mainly consider on-site emissions during manufacturing, without looking at life cycle burdens. Non-certified establishments of the company in developing countries are often excluded from environmental disclosure. Therefore the proper use of corporate environmental disclosure by stakeholders calls for verification of the coverage, quality tests and completion. The analysis of environmental disclosures of four industry sectors shows that environmental management and therefore environmental disclosure is mostly limited to the process and the organization level of companies' activities and needs to be carefully checked. It would be desirable to have information at the product or function level available. It can be

\footnotetext{
${ }^{5}$ The A energy label designates an energy-efficient car while the G label reveals a car that is not energy efficient.

${ }^{6} \mathrm{CO}_{2}$ emissions per passenger kilometer would be an even better indicator. Unfortunately we did not find reliable data on the occupancy of different car models, therefore we had to simplify and use $\mathrm{CO}_{2}$ emission data per vehicle kilometer.
} 
concluded that the value of corporate environmental disclosures for stakeholders is currently restricted since it often excludes main impacts. They only provide indications of the existence and the quality of a company's environmental management systems and only show what is measured at the company. Environmental disclosures can also be seen as a possibility for a facultative external review.

The quantitative corporate environmental reporting from 2002 to 2006 does not enable a comprehensive assessment of the environmental performance of companies. Subsequently, quantitative corporate environmental disclosures do not allow identification of environmental priorities, opportunities and risks because they generally do not consider the whole life cycle of a product or service, and therefore they do not satisfy the needs of stakeholders. Stakeholders' needs would be better met with the following.

- An overview of the total and most important environmental impacts due to the product portfolio (core business) of a company. A possible method to satisfy this need is to disclose environmental burden and influence matrices.

- More reliable, more complete and more accurate data. Life cycle (top-down) approaches applied to product portfolios can be used for a rapid screening and the verification and the improvement of the reliability and accuracy of corporate quantitative environmental disclosures (bottom-up approach).

- Standardized quantitative corporate environmental disclosures with a life cycle perspective. Existing reporting guidelines such as the Global Reporting Initiative guidelines are steadily increasing their divulgation but they do not sufficiently promote and encourage the disclosure of environmental information on the whole life cycle of products and services. According to Brink and Woerd (2004) they also include too many indicators.

- Product- and sector-specific key performance indicators, particularly for investors (Butz, 2005). In contrast to financial reporting, standardized key performance indicators are not yet applied in environmental reporting (Park and Brorson, 2005).

As long as external auditors or reviewers do not verify that environmental reporting covers the whole life cycle of all important products and services commercialized by the companies, stakeholders should not rely on quantitative corporate environmental disclosures for the evaluation of the environmental performance. To ensure that companies and potential users of environmental disclosures are always aware of the percentage of environmental impacts and establishments covered by environmental disclosures, it is necessary that this information is figured in a central part of environmental reports and in every kind of corporate environmental disclosure. In order for companies to improve the overall environmental performance, they have to estimate the total environmental impact of their products and services; reporting on a site level only is not sufficient. Evaluations should be more comprehensive and aim at improving sustainability beyond the corporate 'footprint'. Going beyond the organizational level is the only improvement that makes sense from a scientific perspective in order to avoid a simple displacement of impacts from one life cycle stage to another. Evaluations should consider

(i) a majority of the environmental burdens along the life cycle of products and services ('vertical integration' over the whole value chain, use and disposal),

(ii) the most important environmental impacts and improvement potential of all relevant product groups of the company (e.g. using environmental influence matrices),

(iii) key performance indicators with an incentive character for the improvement of the overall environmental performance of products commercialized.

As the Global Reporting Initiative (2006) proposes, quantitative data should be applied wherever possible. The focus of this article lies on quantitative disclosure also because quantitative disclosures have a large influence on decision making in the financial sector, or, as Behn (2003) stated, 'what gets measured gets done'. Still, important environmental impacts that cannot be considered quantitatively should not be omitted, but discussed qualitatively.

The life cycle assessment of the environmental impacts of new product groups seems unavoidable. Once a basic set of products is thoroughly analyzed, ${ }^{7}$ the analysis of new similar products is simple. It can be based on existing

${ }^{7}$ It must be acknowledged that process-based LCA of complex products has historically been rather time consuming, but the increasing availability of databases for a large number of processes has greatly simplified this task. 
evaluations by adapting the parameters and inputs that changed. Companies with a high number of suppliers cannot always gather environmental data of all companies in their supply chain. Therefore we suggest using stateof-the-art LCA databases such as ecoinvent (ecoinvent, 2008) and input-output LCA for all process and life cycle stages where no environmental impact data is available from suppliers.

\section{Discussion of the Methodological Contribution}

The article shows how to compare the environmental performance of products or product portfolios of companies. It also introduces the concept of the environmental influence matrix, as a new element in the literature on environmental decision-making. The methods proposed for analyzing, testing and assessing corporate environmental disclosure are rather coarse but comprehensive and efficient. They might be well adapted for stakeholders in the financial service industry such as analysts for socially responsible investment funds or any stakeholders who want to take into account environmental aspects of the products and services they buy and sell. Concepts and methods introduced in this article might also help to improve quantitative environmental disclosure of companies, GRI guidelines, the greenhouse gas protocol and the quality of the data collected by the carbon disclosure project.

\section{Context, Limitations and Outlook}

The approach suggested in this article has already been tested by companies and several elements are in use for the environmental evaluation of companies (e.g. Centre Info, 2007). The framework applies to all industries and products. However, for products implying little energy consumption and high potential damage for human health or ecosystems, the test using the ratio of carbon dioxide emissions and energy consumption is not sufficient. It can be complemented with data quality tests based on very similar direct or indirect dependencies between other available environmental data.

Acknowledging that one of the most important positive effects of sustainability ratings occur when independent rating agencies present and discuss their assessment with companies, it is definitely not the aim of this article to criticize environmental reporting as such, but to propose ways to focus reporting on what matters.

It can be assumed that the importance of the extended producer responsibility principle will continue to increase. In particular, companies relying on the value of their brand and their reputation can be made responsible for the environmental impacts of the products they sell. Therefore, all companies claiming to be best in class should assess the total environmental impacts of their products and services. Extended producer responsibility is becoming an increasingly important motivation for considering reputation risks and opportunities through the whole life cycle of products, even though reporting principles for quantitative environmental data are behind policies such as the integrated product policy of the European Union. In the automotive sector it would be important to investigate how companies could be motivated to adopt life cycle thinking even if short-term margins are higher with heavy cars than with light low-consumption cars for example. To accelerate the diffusion of long-term and life cycle thinking, the following research questions are of interest: which companies use life cycle thinking and what are determinants for the adoption of life cycle thinking?

\section{Acknowledgements}

The authors are grateful to Centre Info (co-founder of the SiRi Company) for funding a part of this research and also for providing their database on the environmental evaluation of quoted companies. We would also like to thank Professor Thomas Dyllick and Urs Schenker for significant feedback on an early stage version of this article, and Shanna Shaked and two anonymous reviewers for valuable comments on the manuscript.

\section{References}

Allenby BR. 2000. Implementing Industrial Ecology: the AT\&T Matrix System. Interfaces 30(3): 42-54.

Automotive News. 2003. 2002 Global Market Data Book. Crain Communications. 
Behn RD. 2003. Why measure performance? Different purposes require different measures. Public Administration Review 63(5): 586-606. Berlin J, Sonesson U, Tillman AM. 2008. Product chain actors' potential for greening the product life cycle. the case of the Swedish postfarm milk chain. Journal of Industrial Ecology I2(I): 95-IIO.

Brammer S, Pavelin S. 2006. Voluntary environmental disclosures by large UK companies. Journal of Business Finance and Accounting 33(7/8): II68-II 88 .

Braunschweig A, Bär P, Rentsch C, Schmid L, Wüest G. I997. Methode der ökologischen Knappheit - Ökofaktoren 1997. Methode für die Gewichtung in Ökobilanzen. Federal Office for the Environment: Bern.

Brink T, Woerd F. 2004. Industry specific sustainability benchmarks: an ECSF pilot bridging corporate sustainability with social responsible investments. Journal of Buisnesss Ethics 55: 187-203.

Brunklaus B, Thormark C, Baumann H. 2008. Beyond the energy accounting of buildings: introducing environmental and actor perspectives in comparisons of passive and conventional buildings. In Organising Matters for the Environment: Environmental Studies of Housing Management and Buildings, Brunklaus B, Ph.D. dissertation, Chalmers University of Technology.

Butz Ch. 2005. Weniger ist oft mehr - ein neuer Ansatz im SRI-Research, Pictet-Arbeitspapier. Banque Pictet: Genf.

Bureau of Economic Analysis (BEA). I997. Input-Output Accounts. http://www.bea.gov [Io November 2005].

Castro NR, Chousa JP. 2006. An integrated framework for the analyses of sustainability. Business Stratey and the Environment I5: 322333.

Centre Info. 2007. The Carbon Intensity of Car Manufacturers - a Sector Study using envIMPACT. Centre Info: Fribourg, Switzerland.

Cormier D, Magnan M. 2003. Environmental reporting management: a European perspective. Journal of Accounting and Public Policy 22(I): 43-62.

Cormier D, Magnan M, Van Velthofen B. 2007. Environmental disclosure quality in large German companies: economic incentives, public pressures or institutional conditions? European Accounting Review I4(I): 3-39.

Dyllick T, Belz F, Hugenschmidt H, Koller F, Laubscher R, Paulus J, Sahlberg M, Schneidewind U. I994. Ökologischer Wandel in Schweizer Branchen. Haupt: Bern.

Dyllick T, Belz F, Schneidewind U. I997. Ökologie und Wettbewerbsfähigkeit. Neue Zürcher Zeitung: Zürich.

ecoinvent (ecoinvent I.O, I.I, I.2, I.3, 2.0). 2003-2008. Database for Life Cycle Assessment. Swiss Center for Life Cycle Inventories: Dübendorf, Switzerland. http://www.ecoinvent.ch [Io September 2007].

Freedman M, Patten DM. 2004. Evidence on the pernicious effect of financial report environmental disclosure. Accounting Forum 28: 274I.

Frischknecht R, Jungbluth N, Althaus HJ, Doka G, Dones R, Heck T, Hellweg S, Hischier R, Nemecek T, Rebitzer G, Spielmann M. 2005. The ecoinvent database: overview and methodological framework. International Journal of Life Cycle Assessment Io(I): 3-9.

Gerde VW, Logsdon JM. 200I. Measuring environmental performance: use of the toxics release inventory (TRI) and other US environmental databases. Business Strategy and the Environment Io: 269-285.

Global Reporting Initiative (GRI). 2006. Sustainability Reporting Guidelines. GRI: Amsterdam. http://www.globalreporting.org [20 August 2007].

Gouldson AP, Sullivan R. 2007. Corporate environmentalism: tracing the links between policies and performance using corporate reports and public registers. Business Strategy and the Environment I6: I-II.

Gray R, Javad M, Power D, Sinclair D. 200I. Social and environmental disclosure and corporate characteristics: a research note and extension. Journal of Business Finance and Accounting 28(3/4): 327-356.

Guthrie J, Parker L. I990. Corporate social disclosure practice: a comparative international analysis. Advances in Public Interest Accounting 3: I59-I73.

Hackston D, Milne MJ. I996. Some determinants of social and environmental disclosures in New Zealand companies. Accounting, Auditing and Accountability Journal 9(I): 77-108.

Hahn T, Scheermesser M. 2006. Approaches to corporate sustainability among German companies. Corporate Social Responsibility and Environmental Management 13: I50-165.

Hertwich E. 2005. Life cycle approaches to sustainable consumption: a critical review. Environmental Science and Technology 39(13): 46734684 .

ISO I4020. 2002. Environmental Labels and Declarations - General Principles. International Organization for Standardization: Geneva.

ISO I4040. 2006. Environmental Management - Life Cycle Assessment - Principles and Framework. International Organization for Standardization: Geneva.

Jolliet O, Margni M, Charles R, Humbert S, Payet J, Rebitzer G, Rosenbaum R. 2003. IMPACT 2002+: a new life cycle impact assessment methodology. International Journal of Life Cycle Assessment 8(6): 324-330.

Kaenzig J, Jolliet O. 2006. Umweltbewusster Konsum: Schlüsselentscheide, Akteure und Konsummodelle/Consommation Respectueuse de l'Environnement: Décisions et Acteurs Clés, Modèles de Consommation, Umwelt-Wissen o6ı6/Connaissance de l'Environnement o6ı6. Swiss Federal Office for the Environment: Bern. http://www.umwelt-schweiz.ch/publikationen [30 May 2008].

Kaenzig J, Jolliet O. 2007. Prioritising sustainable consumption patterns: key decisions and environmental gains. International Journal of Innovation and Sustainable Development 2(2): I40-I54.

Kahn Ribeiro S, Kobayashi S, Beuthe M, Gasca J, Greene D, Lee DS, Muromachi Y, Newton PJ, Plotkin S, Sperling D, Wit R, Zhou PJ. 2007. Transport and its infrastructure. In Climate Change 2007: Mitigation, Contribution of Working Group III to the Fourth Assessment Report of the Intergovernmental Panel on Climate Change, Metz B, Davidson OR, Bosch PR, Dave R, Meyer LA (eds). Cambridge University Press: Cambridge; $323-385$.

Kassinis G, Vafeas N. 2006. Stakeholder pressures and environmental performance. Academy of Management Journal 49(I): I45-I59. 
Kautto P. 2006. New instruments - old practices? The implications of environmental management systems and extended producer responsibility for design for the environment. Business Strategy and the Environment 15: 377-388.

Kerret D, Gray GM. 2007. What do we learn from emissions reporting? Analytical considerations and comparison of pollutant release and transfer registers in the United States, Canada, England, and Australia. Risk Analysis 27(I): 203-223.

Kolk A, van der Veen M, Pinkse J, Fortanie F. 2005. KPMG International Survey of Corporate Responsibility Reporting, University of Amsterdam, KPMG Global Sustainability Service. KPMG: Amsterdam.

Labouze E, Monier V, Le Guern Y, Puyou JB. 2003. Study on External Environmental Effects Related to the Life Cycle of Products and Services, Final Report Version 2 to the Directorate General Environment of the European Commission. BIO Intelligence Service/O2: Paris, France.

Lenzen M, Murray J, Sack F, Wiedmann T. 2007. Shared producer and consumer responsibility - theory and practice. Ecological Economics 6I(I): $27-42$.

Leontief WW. I936. Quantitative input and output relations in the economic systems of the United States. Review of Economic Statistics I8(3): I05-I25.

Llena F, Moneva JM, Hernandez B. 2007. Environmental disclosures and compulsory accounting standards: the case of Spanish annual reports. Business Strategy and the Environment 16: 50-63.

Moll S, Watson D. 2009. Environmental Pressures from European Consumption and Production - a Study in Integrated Environmental and Economic Analysis. European Topic Centre on SCP/EEA.

Niskanen J, Nieminen T. 200I. The objectivity of corporate environmental reporting: a study of Finnish listed firms' environmental disclosures'. Business Strategy and the Environment Io(I): 29-37.

Park J, Brorson T. 2005. Experiences of and views on third-party assurance of corporate environmental and sustainability reports. Journal of Cleaner Production I3: 1095-IIo6.

Pennington DW, Potting J, Finnveden G, Lindeijerd E, Jolliet O, Rydberg T, Rebitzer G. 2004. Life cycle assessment Part 2: Current impact assessment practice. Environment International 30: 72I-739.

Perrini F, Tencati A. 2006. Sustainability and stakeholder management: the need for new corporate performance evaluation and reporting systems. Business Strategy and the Environment 15: 296-308.

Pflieger J, Fischer M, Kupfer Th, Eyerer P. 2005. The contribution of life cycle assessment to global sustainability reporting of organizations. Management of Environmental Quality: an International Journal I6(2): I67-179.

Rebitzer G. 2005. Enhancing the Application Efficiency of Life Cycle Assessment for Industrial Uses, Thèse 3307, Ecole Polytechnique Fédéral de Lausanne.

Rebitzer G, Ekvall T, Frischknecht R, Hunkeler D, Norris G, Rydberg T, Schmidt WP, Suh S, Weidma BP, Pennington DW. 2004. Life cycle assessment Part I: Framework, goal and scope definition, inventory analysis, and applications. Environment International 30: 70I-720. http://biblion.epfl.ch/EPFL/theses/2005/3307/EPFL_TH3307.pdf [8 May 2007].

Rehfeld KM, Rennings K, Ziegler A. 2006. Integrated product policy and environmental product innovations: an empirical analysis. Ecological Economics 6I(I): 9I-IoO.

Schaltegger S, Wagner M. 2006. Integrative management of sustainability performance, measurement and reporting. International Journal of Accounting, Auditing and Performance Evaluation 3(I): I-I9.

Schweimer G, Levin M. 2000. Life Cycle Inventory for the Golf A4. Center of Environmental Systems Research, University of Kassel-Research, Environment and Transport, Volkswagen AG: Wolfsburg.

SiRi Company. 2003. SiRi Global Profiles on Automotive Companies, Banks, Technology and Hardware Equipment Companies, Pharmaceutical Companies. Centre Info: Fribourg, Switzerland.

Suh S. 2004. Functions, commodities and environmental impacts in an ecological economic model. Ecological Economics 48(4): 45I-467.

Suh S, Lenzen M, Treloar GJ, Hondo H, Horvath A, Huppes G, Jolliet O, Klann U, Krewitt W, Moriguchi Y, Munksgaard J, Norris G. 2004. System boundary selection in life cycle inventories using hybrid approaches. Environmental Science and Technology 38(3): 657-664.

Suh S, Nakamura S. 2007. Five years in the area of input-output and hybrid LCA. The International Journal of Life Cycle Assessment I2(6): $35^{\mathrm{I}-35^{2}}$.

TCS, EnergieSchweiz. 2004. Consumption Tables for 2003. Swiss Federal Office of Energy: Bern. http://www.energieetiquette.ch [3 June 2004 ].

Trucost. 2007. Trucost Methodology Overview. http://www.trucost.com/Trucost_Methodology_Companies.pdf [20 August 2007].

Tukker A, Huppes G, Guinée J, Heijungs R, de Koning A, van Oers L, Suh S, Geerken T, Van Holderbeke M, Jansen B, Nielsen P. 2006. Environmental Impact of Products (EIPRO). Analysis of the Life Cycle Environmental Impacts Related to the Final Consumption of the EU-25, Technical Report EUR 22284 EN. Institute for Prospective Technological Studies, Joint Research Centre (DG JRC): Brussels, Belgium.

Tukker A, Jansen B. 2006. Environmental impacts of products: a detailed review of studies. Journal of Industrial Ecology Io(3): I59-I82.

Tukker A, Poliakova E, Heijungs R, Hawkinsc T, Neuwahld F, Rueda-Cantuche JM, Gljume S, Moll S, Osterhaveng J, Bouwmeesterg M. 2009. Towards a global multi-regional environmentally extended input-output database. Ecological Economics 68(7): 1928-1937.

UNEP. 2004. Why Take A Life Cycle Approach? United Nations Environment Programme: Paris Cedex.

Weber T, Koellner T, Habegger D, Steffensen H, Ohnemus P. 2008. The relation between the GRI indicators and the financial performance of firms. Progress in Industrial Ecology - an International Journal 5(3): 236-254.

Weis M. 2007. Der Klimawandel als Herausforderung für die Finanzbranche. UmweltWirtschaftsForum I5(2): II6-I22.

Yongvanich K, Guthrie J. 2006. An extended performance reporting framework for social and environmental accounting. Business Strategy and the Environment 15(5): 309-321. 